\title{
Et billede fra sønderjydsk altergang o. 1650
}

\author{
Af H. F. Petersen
}

Der findes i danske kirker to fremstillinger af altergangen efter reformationen: dels et antemensale (malet beklædning af alterbordets forside) i Torslunde kirke (Sjælland) og dels et maleri på altertavlen i Landet kirke på Lolland. ${ }^{1}$ )

Førstnæunte er fra 1561 og skildrer på samme billede såvel dåb ved døbefonten som prædiken fra prædikestolen og altergang med altergæster, som knæler på gulvet. Det andet billede er fra 1582: Altergæsterne knæler ligeledes pá det bare gulv, og præsten bærer både præstekjole og messesærk og messehagel.

Mig bekendt findes ingen billeder fra sønderjysk altergang i nogen kirke. Men vi kan danne os et godt billede om, hvorledes man gik til alters $i$ en sønderjysk landsbykirke ved hjælp af vor ældste bevarede kirkebog, nemlig den fra Aastrup, $\left.{ }^{2}\right)$ som begynder 1574.

Der holdtes altergang hver søndag som regel, hvis ikke, nævnes udtrykkelig "nemo « (ingen); er der kun én altergæst, står der "solus" eller "sola " (alene). Var der bryllup, bortfaldt altergangen: 7. søndag efter Trinitatis 1577 er Mickel Bunde til alters, den følgende søndag står hans bryllup: "nemo pp. nuptias Mickel Bunde.«

Enten gik man alene eller sammen med sin husstand. F. eks. er 2. juledag 1576 til alters "Mickel Niellsen med sin hustru oc quind" (tjenestepige), 1580 »Mickel Bunde meth sin suen (karl)《 og en anden gang "min (præstens) gamell suen, Jesper, solus« og "Chresten Nygaard meth sin hustru, moder oc datter." I henhold til Luthers udtalelser bestræbte man sig for at gå til alters 2 gange årligt.

Op imod 1600 får kirkerne 2 knæfald foran altret, et tilhøjre og et tilvenstre. Først gik mændene til alters, derefter kvinderne.

1) Gengivet hos L. P. Fabricius: Danmarks kirkehistorie II (1936), s. 210 og 296.

2) Landsarkivet i Åbenrå, i uddrag gengivet af Thomas Matthiesen i Schriften des Vereins f. S.-H.sche Kirchengesch. 2. rk. VII (1925), s. 434 ff. 
Ser man på nedenstående billede, lægger man mærke til, at præsterne ikke er iført messetøj, men præstekjole med pibekrave. Nár nogle mænd knælende har modtaget brødet ved venstre knæfald, går de om bag altret og knæler derefter ved højre knæfald for at modtage vinen. Mændene og kvinderne bærer datidens dragter.

Billedet er et kobberstik og stammer fra titelbladet af en omfangs-

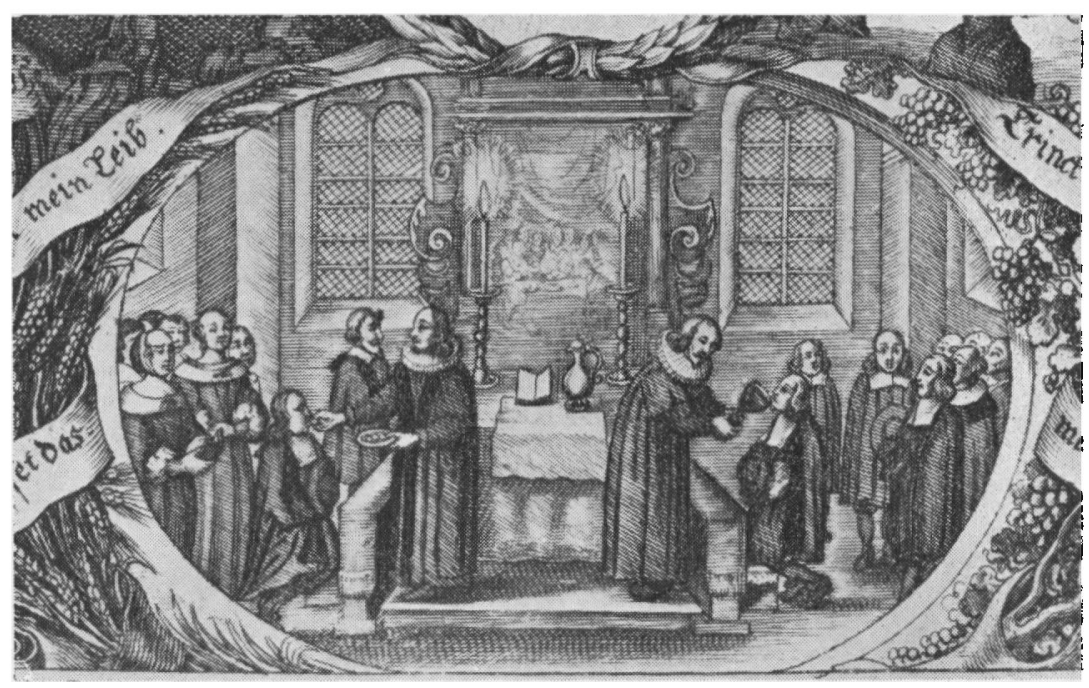

rig sakramentspostil fra 1668, udgivet af præsten i Glückstadt (den kongelige del af hertugdømmerne), Gothofrid Kilian. Bogens fulde titel er "Postilla Sacramentalis, ab amicis dicta Polyglotta, das ist Erklärung der Sonntags-Evangelien durchs gantze Jahr / da aus einem jedweden Evangelio die Lehr vom heiligen Abendmal den Christlichen Communicanten zur Vorbereitung und Unterricht angeführet wird. Vorher ist der Griechische Text eines jedweden Evangelij gesetzet / nebest der Syrischen Version mit Hebreischen Litern wie auch Vulgata, cum Versione Gallicâ, Italicâ, Hispanicâ, Anglicâ et Belgicâ ..."

Til bogen ${ }^{3}$ ) har under 10. dec. 1667 kongens generalsuperintendent Stephan Klotz skrevet en længere fortale om altergangen, hvori han lægger stor vægt på den rette forberedelse for at modtage nadveren værdig.

9) Findes $i$ det Kgl. Bibliothek i København, Staats- und Universitätsbibl. i Hamborg og Klosterbibliotheket i Preetz.

4) $\mathrm{Nu}$ aftrykt af Wilh. Jensen $i$ "Schriften des Vereins f. S.-H.sche Kirchengeschichte" 2 . rk. XII (1954), s. 5, 6, 7, 21, 24, 25, 27 og 30. 
Hans embedsbroder $\mathrm{i}$ de gottorpske dele af hertugdømmerne, generalsuperintendent Jakob Fabricius kommer i sin indberetning fra sin visitatsrejse $1639^{4}$ ) gentagne gange ind på altergangen. Han nævner således: Skik er 2 gange årlig, søndagen før jul og palmesøndag. Før 1. altergang holdes der flere steder en slags konfirmandprøve for børnene. En kvinde formanes, da hun ikke har været til alters i 12 år, hendes 26årige søn aldrig. En mand er fejlagtig kommen til alters uden foregående offentlig skrifte. Koner og piger går til alters mellem hverandre, imod kirkeordningen. Et sted knæler alle ned, medens indstiftelsesordene læses. Flere steder findes intet messetøj; det er forsvundet $\mathbf{i}$ krigens tid. Man skal skrifte på det sted, hvor man har syndet. I Preetz kloster holdes ikke altergang hver søndag.

I sommermånederne 1649 foretog Klotz sin første visitatsrejse i Haderslev amt. I sin indberetning til kongen ${ }^{5}$ ) udtaler han sig kun i almindelighed, også om altergangen. Men: »fremtidig måtte der agtes på, at der ikke kun nogle steder, men alle vegne under nadverens uddeling siges til altergæsterne: "Jesu Kristi legeme for dig hengiven styrke og opholde dit legeme og din sjæl til det evige liv «, ligeså "Jesu Kristi blod etc. «. Den ene gør det, den anden undlader det. Desuden holder han på, at præsterne alle vegne om søndagen og i skriftestolen skal modtage den enkeltes skriftemål og give ham absolution.

5) Rigsarkivet. 